\title{
Los Sitios Reales durante el Trienio Liberal: la cesión de una parte del patrimonio real a la nación*
}

\section{Royal sites during the Liberal Triennial (1820-1823): the transfer of part of the royal heritage to the nation}

\author{
Félix LABRADOR ARRoYo \\ Universidad Rey Juan Carlos \\ Felix.labrador@urjc.es \\ http://orcid.org/0000-0001-9040-4807
}

Fecha de recepción: 17-10-2019

Fecha de aceptación: 17-01-2020

\section{RESUMEN}

El triunfo del pronunciamiento del coronel Riego en Cabezas de San Juan supuso cambios en el patrimonio real. Los liberales lo consideraban un anacronismo que debía de ser abolido, siendo la nación la nueva titular de sus derechos y bienes y la que señalaría los espacios destinados o reservados al monarca y a su familia necesarios para el decoro y desempeño de sus funciones, de acuerdo con lo dispuesto en la Constitución de 1812. Además, en un contexto de necesidad de la hacienda nacional estos espacios, una vez nacionalizados generarían una importante fuente de ingresos. En este trabajo, a través de documentación primaria, fundamentalmente del Archivo General de Palacio, analizaremos el proceso de cesión por parte de la corona de una serie de bienes y espacios reales a la nación, —nada despreciables- las consideraciones que este proceso generó entre los liberales y los cambios que está cesión produjo en la gestión del patrimonio real. Sin embargo, el fin del Trienio impidió que se consolidase una línea de actuación concreta sobre el real patrimonio

Palabras clave: Trienio liberal, Fernando VII, reales sitios, patrimonio real, patrimonio nacional. Topónimos: España.

Período: 1820-1823.

\footnotetext{
* Este trabajo se inscribe dentro de las actuaciones de los proyectos 'Madrid, Sociedad y Patrimonio: pasado y turismo cultural" (H2019/HUM-5989) del Programa de actividades de I+D entre grupos de investigación de la CAM en Ciencias Sociales y Humanidades 2019, cofinanciado por el Fondo Social Europeo y "Las raíces materiales e inmateriales del conservacionismo ambiental de la Península Ibérica (siglos XV-XIX)" (SUSTINERE), acción financiada por la Comunidad de Madrid en el marco del Convenio Plurianual con la Universidad Rey Juan Carlos en la línea de actuación 1, Programa de "Estímulo a la investigación de jóvenes doctores"
} 


\section{ABSTRACT}

The triumph of Colonel Riego's pronunciamiento in Cabezas de San Juan resulted in changes in royal heritage. The liberals regarded the latter as an anachronism that needed to be abolished: the nation was now the new owner of its rights and assets. In accordance with what had been established in the Constitution of 1812, it was the nation that had to determine the space reserved for the king and his family, to ensure decorum and the discharge of their duties. Moreover, in the context of the necessities of the national treasury, these spaces, once nationalised, would constitute an important source of income. This article, through primary sources mainly from the "Archivo Nacional de Palacio", analyses the process of transfer of a significant series of assets and royal spaces from the Crown to the nation, the debate this generated among the liberals and the consequences this cession had for the management of royal heritage. Nevertheless, the end of the Trienio impeded the consolidation of a concrete line of action vis-à-vis royal heritage.

Key words: Trienio liberal, Fernando VII, Royal Sites, Royal Heritage, National Heritage. Toponyms: Spain.

Period: $1820-1823$.

\section{INTRODUCCIÓN}

Algunos de los diferentes decretos aprobados por las Cortes gaditanas entre 1811 y 1813, así como la Constitución de 1812, trataban de redefinir el papel de los bienes de la Corona atendiendo a los ideales constitucionales y al nuevo modelo de Estado, donde la soberanía recaía en la Nación ${ }^{1}$. De este modo, por ejemplo, en la Constitución se estableció la separación entre la Corona y el Estado y la limitación del patrimonio real, al reconocer la existencia de unos bienes vinculados a la institución monárquica, pero de los que el soberano no podía disponer libremente ${ }^{2}$ y, poco después, en el Decreto de 11 de octubre de 1813, se reconocía que "en España no se conocía patrimonio privado del rey, y esta declaración sería opuesta al sistema constitucional, según el cual, las Cortes debían de señalar su dotación y los palacios propios para su recreo"3.

En 1814, Fernando VII declaraba nulos los actos emanados en Cádiz, así como la propia Constitución, reafirmando el carácter privado del patrimonio real ${ }^{4}$. Sin embargo, las ideas liberales volvieron a imponerse tras el éxito del pronunciamiento de Rafael de Riego, el primero de enero de 1820, en Cabezas de San Juan. Para los liberales el patrimonio real era algo anacrónico, que debía de ser abolido, al ser la nación la nueva titular de sus derechos. Al mismo tiempo, se convertía en una importante fuente de recursos para la hacienda ${ }^{5}$. Ahora bien, se reconocía que se tenía que destinar o reservar al monarca y a

1 E. García Monerris y C. García Monerris, Las cosas del rey. Historia política de una desavenencia (18081874), Madrid, Akal, 2015, p. 12. En este trabajo no analizaremos el patrimonio real en la Corona de Aragón magistralmente estudiado en esta obra.

2 M. Artola y R. Flaquer Montequi, La Constitución de 1812, Madrid, Iustel, 2008, p. 107.

3 Véase, C. García Monerris y E. García Monerris, "La nación y su dominio: el lugar de la corona”, en Historia Constitucional.Revista electrónica, 5, (2004), p. 187 y F. Cos-Gayón, Historia jurídica del Patrimonio Real, Madrid, Imprenta de Enrique de la Riva, 1881, p. 142.

4 Sobre este proceso véase F. Labrador Arroyo, "'Naturaleza y esencia de los artículos productivos'. La situación del patrimonio real entre 1814-1820", Tiempos Modernos. Revista Electrónica de Historia Moderna, 39.2, (2019), pp. 488-512 y E. García Monerris y C. García Monerris, "Las cosas del rey", en Las cosas del rey..., pp. 51-60.

5 Para un contexto general, véanse los clásicos, pero todavía vigentes estudios de J. Fontana, Hacienda y 
su familia aquellos lugares simbólicos y necesarios para el decoro y desempeño de sus funciones ${ }^{6}$.

En este contexto, poco después de jurar Fernando VII la Constitución gaditana y de aceptar la creación, el 9 de marzo de 1820, de una Junta Provisional de Gobierno, que dio paso a la primera administración liberal donde Canga Argüelles ejerció como ministro de Hacienda ${ }^{7}$, el mayordomo mayor, el conde de Miranda, don Pedro de Alcántara y Álvarez de Toledo, informaba, el 14 de marzo, al secretario de Estado, que el monarca le había comunicado verbalmente su deseo de que, como mayordomo mayor, mantuviese los negocios pertenecientes a su real casa y patrimonio, pero no como secretario de Estado -como lo tenía-, sino como Jefe General de Palacio y de la Administración.

Esta cuestión fue tratada por la Junta Provisional un día más tarde y acordaron refrendarla con lo que, ese mismo día, el 15 de marzo, el conde de Miranda escribía al secretario de Gracia y Justicia para trasmitirle el deseo real de ajustar la administración de su real patrimonio a lo estipulado en el capítulo $5^{\circ}$ de la Carta Magna ${ }^{8}$, manteniendo la separación entre los asuntos de la Real Casa y Patrimonio con los del Estado, que se había establecido durante el primer periodo liberal. Días más tarde, el mayordomo mayor hacía ver al monarca la necesidad de poner la corte de acuerdo con el modelo constitucional ${ }^{9}$. De este modo, desde palacio se trataba de anticiparse a los cambios y de adecuarse a la nueva situación.

\section{LA ANTICIPACIÓN DE LA CORONA EN RELACIÓN CON EL REAL PATRIMONIO.}

El 27 de marzo se solicitaba a los administradores de los palacios y reales sitios la remisión de los títulos de propiedad de las posesiones y bienes que guardaban y administraban para demostrar al nuevo gobierno liberal que el rey tenía, por derecho, un patrimonio propio, diferente al que podía tener el Reino ${ }^{10}$ (dos días antes, la Junta Provisional había solicitado el reintegro a la nación del valle de Alcudia y de la Albufera valenciana, adquiridos por Carlos III ${ }^{11}$ ).

Sin tiempo para recibir las respuestas de las distintas posesiones, Fernando VII, el 3 de abril de 1820, mandaba poner fin a los privilegios exclusivos y privativos del real patrimonio, previo informe de la Junta Provisional, que llevaba con la cuestión desde finales de marzo. De este modo, se procedía a suspender, de facto, la Junta Suprema Patrimonial de Apelaciones y el fuero privativo de los oficiales de la Real Casa y Patrimonio, siendo

Estado en la crisis del antiguo régimen español: 1820-1833, Madrid, Instituto de Estudios Fiscales, 1973, M. Artola, La Hacienda del siglo XIX, progresistas y moderados, Madrid, Alianza Universidad, 1986, F. Comín, Las cuentas de la hacienda preliberal en España (1800-1855), Madrid, Servicio de Estudios del Banco de España, 1990.

6 E. García Monerris y C. García Monerris, "Monarquía y patrimonio en tiempos de revolución en España", Diacronie [En línea], 16.4 (2013), pp. 2-3. Puesto en línea el 1 diciembre 2013, consultado el 30 abril 2019. URL: http://journals.openedition.org/diacronie/855; DOI : 10.4000/diacronie.855

7 B. E. Buldain Jaca, "El poder en 1820: la Junta Provisional y el Gobierno", Espacio, Tiempo y Forma. Serie V. Historia Contemporánea, 1, (1988), p. 21.

8 Archivo General de Palacio (en adelante AGP), Reinados, Fernando VII, caja 330, exp. 15.

9 Ibíd, exp. 16. Esta situación se confirmó por orden de 24 de septiembre de 1820. A.M. Moral Roncal, El enemigo en Palacio: afrancesados, liberales y carlistas en la Real Casa y Patrimonio (1814-1843), Alcalá de Henares, Universidad de Alcalá, 2005, pp. 77-87 y D. del M. Sánchez González, "El tránsito de la casa de Fernando VII a la de Isabel II: la Junta de Gobierno de la Casa Real y Patrimonio (1815-1840)", en Corte y Monarquía en España, Madrid, UNED, 2003, pp. 29-66.

10 AGP, Administración General (en adelante AG), leg. 359.

11 E. García Monerris y C. García Monerris, Las cosas del rey..., p. 70. 
trasladadas las causas al Tribunal Supremo y a las diferentes audiencias. Asimismo, se retomó el Decreto de 19 de julio de 1813, donde se habían abolido los privilegios del real patrimonio ${ }^{12} \mathrm{y}$, poco después, el 13 de abril, el monarca restableció el Decreto LXXXII, de 6 de agosto de 1811, a través del cual se derogaban los privilegios exclusivos, privativos y prohibitivos del señorío ${ }^{13}$.

En este contexto, comenzaron a llegar a palacio los informes desde los reales sitios solicitados previamente por la mayordomía mayor. Así, el 5 de abril de 1820, el administrador de San Fernando, don Pedro Antonio Sobrado, remitía los documentos de propiedad y las mejoras económicas que se hicieron en este real sitio ${ }^{14} \mathrm{y}$, el 9 de abril, el contador interino de San Ildefonso, Riofrío y Valsaín, Juan Sánchez Godínez enviaba todos los títulos de propiedad de estos lugares diferenciando entre aquellos en donde el monarca tenía títulos de compra, donación o herencia, por señalar algunos casos ${ }^{15}$.

Con la información disponible y adelantándose a los proyectos del Estado, desde palacio, el 28 de abril de 1820, se proponía de manera inesperada, ceder una parte del real patrimonio a la nación, entregándola a la Junta Nacional del Crédito Público para que, con su venta, se aumentase la masa de bienes destinados al pago de la deuda. Esta decisión se tomaba por el "paternal amor a los heroicos súbditos que me destinó la Providencia a hacer felices con renovar cuantos decretos benéficos publicaron las Cortes, prestándoles mi real sanción, deseando anticiparles en lo que de Mi pende, los bienes que deben esperarse de las que van a reunirse y aspirando a fomentar más y más una justa confianza en los acreedores del Estado con el aumento de los recursos del Crédito Público"16.

Como refirió, años más tarde, don Tomás Cortina, consultor general de la Real Casa y Patrimonio, Fernando VII quiso recompensar a la nación pues se hallaba "persuadido de que no era posible consiga [sic] la monarquía toda la unión y felicidad que necesita, y a que debe aspirar, mientras todos los españoles no sean iguales en goces y en cargas, en derechos y deberes"17. De esta manera, el monarca se anticipaba al gobierno liberal y actuaba de acuerdo, por un lado, con el artículo 214, capítulo 5, título $4^{\circ}$ de la Constitución gaditana, en donde se definían los bienes que pertenecían al rey ${ }^{18} \mathrm{y}$, por otro, con lo dispuesto en el capítulo $6^{\circ}$, título $2^{\circ}$, del Decreto de 13 de diciembre de 1813 , en donde se señalaba que una serie de heredamientos y posesiones reales se dedicarían al pago de la deuda pública $^{19}$. Fernando VII, con todo, se reservaba una parte de su real patrimonio, el que él eligió y consideró, por lo que la Corona y no las Cortes, como señalaba la Constitución,

12 L. López Rodó, El Patrimonio Nacional, Madrid, CSIC, 1954, p. 181. Gaceta de Madrid, de 9 de mayo de 1820, núm. 61, p. 391. Disponible en: https://www.boe.es/buscar/gazeta.php (Consultado el 14-7-2019)

13 Colección de los decretos y órdenes que han expedido las Cortes Generales y Extraordinarias desde su instalación en 24 de septiembre de 1810 hasta igual fecha de 1811, Cádiz, Imprenta real, 1811, pp. 193-196. Disponible en: http://www.cervantesvirtual.com/obra-visor/coleccion-de-los-decretos-y-ordenes-que-hanexpedido-las-cortes-generales-y-extraordinarias-desde-su-instalacion-en-24-de-septiembre-de-1810-hasta-igual-fecha-de-1811--0/html/0027b5e4-82b2-11df-acc7-002185ce6064_128.html (consultado el 6-8-2019).

14 Propiedades de San Fernando, AGP, AG, leg. 359.

15 La información fue, posteriormente, remitida desde la mayordomía mayor al Ministerio de la Hacienda encabezado por José Canga Argüelles. Al mismo tiempo, y en sentido contrario, comenzaron a llegar reclamaciones por parte de municipios próximos a los lugares del real patrimonio, solicitando derechos o reclamando aprovechamientos, como ocurrió, por ejemplo, con Colmenar de Oreja y Ontígola respecto al Heredamiento de Aranjuez. A. Ortiz Córdoba, Aranjuez, sitio, pueblo. Aranjuez, 1750-1841, Aranjuez, Doce Calles, 1992, p. 292.

16 Gaceta de Madrid, 9 de mayo 1820, pp. 521-522.

17 Informe, AGP, AG, leg. 864

18 M. Artola y R. Flaquer Montequi, La Constitución de 1812..., p. 107.

19 Gaceta de Madrid, 9 de mayo 1820, pp. 521-522. 
sería la encargada de dirigir esta cesión. (Es oportuno señalar que mientras se realizaban estos documentos las Cortes permanecieron cerradas y no se abrieron hasta el 13 de julio).

Además, sería la Tesorería General de la Real Casa la encargada del pago de los salarios y de los gastos de las posesiones y dependencias que quedarían en manos reales, así como el desembolso de las viudedades, pensiones y orfandades. Mientras que la hacienda nacional se haría cargo de los salarios y gastos producidos en los bienes patrimoniales cedidos a la Nación; debiendo entenderse todo esto sin perjuicio de lo que resolviesen las Cortes y los documentos que se presentasen en defensa de los derechos reales. Asimismo, se recogía que los individuos que pasasen a depender ahora de la nación cesarían en su contribución en el Monte Pío de la Casa Real, así como en los beneficios que disfrutaban ${ }^{20}$.

Por ello, poco después, por orden de 5 de agosto de 1820, se solicitaba a cada uno de los reales sitios una razón individual y clasificada de los gastos, sueldos y pensiones de los oficiales que quedarían bajo el patrimonio real y de aquellos que pasarían a depender de la nación. Como cabía esperar, este punto generó algunas dudas, sobre todo, en los primeros momentos. Así, por ejemplo, el comisionado de la Junta Nacional del Crédito Público escribió, el 20 de octubre, al contador interino de San Ildefonso que él sólo había recibido orden para satisfacer los sueldos mensuales desde el día en que tomó posesión de los jefes y guardas encargados de la custodia de los pinares y matas de San Ildefonso, Pirón y Riofrío, al mando de don Juan de Abril, pero que no tenía noticia del pago de las demás obligaciones anejas a sus destinos, emolumentos que antes gozaban, ni a las viudedades, pensiones y orfandades. Casi un mes más tarde, el 30 de noviembre de 1820, la Contaduría General de la Real Casa recordaba al mayordomo mayor, en relación con el pago de las nóminas de los distintos oficios de San Ildefonso, que era la Nación la encargada del desembolso de los salarios de los oficiales de los bienes que se habían cedido, por mucho que los interesados acudiesen a él ${ }^{21}$.

El 28 de abril de 1820, Fernando VII solicitaba al mayordomo mayor que se dispusiese a formar la relación de los bienes que se separarían del real patrimonio. Para ello, el conde de Miranda volvería a reclamar información a los administradores de los lugares, principalmente, en relación con las propiedades, derechos y bienes ${ }^{22}$. Las respuestas no tardaron en llegar. Así, por ejemplo, el 8 de mayo, Pedro Antonio Sobrado, administrador de San Fernando, señalaba que todos los edificios del real sitio eran de propiedad real. El 16 de mayo, Manuel López Cabaña remitía a palacio la relación de todas las casas que tenía el monarca en San Ildefonso y, ese mismo día, lo hacía Horacio Pérez desde El Pardo. Un día más tarde, el conserje de San Lorenzo de El Escorial expedía la relación de las casas de oficios y demás edificios que pertenecían en exclusiva al monarca y, más tarde, el 30 de marzo de 1821, remitía la información acerca de la Dehesa de los Guadalupes ${ }^{23}$. El 24 de mayo de 1820 se enviaron a palacio, por parte de Ignacio Pérez, la relación de fechas en que se adquirieron las tierras y bienes del real sitio de San Fernando y el administrador interino de El Pardo expedía la relación de las cargas, títulos y derechos que tenía el monarca sobre La Moraleja ${ }^{24}$.

Con la información, el conde de Miranda realizó una primera relación de bienes del

20 Decreto de 28 de abril, ibídem.

21 Memoria de la contaduría general, AGP, AG, leg. 359.

22 Decreto, AGP, Reinados, Fernando VII, caja 2, exp. 2 y AG, leg. 359.

23 Informe El Escorial, AGP, AG, leg. 359.

24 Memoria de El Pardo y la Moraleja, ibíd. 
real patrimonio que serían cedidos a la Nación. La relación fue enviada a través de Agustín Argüelles, el 30 de mayo, al nuevo gobierno. Esta relación de bienes se convirtió en real decreto el mismo día ${ }^{25}$. En él se aprobó la configuración de una comisión cuyos miembros serían nombrados por la mayordomía mayor y la secretaría de Hacienda y se indicaba que ante cualquier duda se tendría que consultar al mayordomo, el cual se pondría de acuerdo con el secretario de Hacienda para su resolución. De este modo, de nuevo, quedaba claro que el control del proceso estaría en manos de palacio y no de las Cortes $^{26}$.

Tras la apertura de las Cortes ordinarias, el 13 de julio, se procedió a debatir el decreto de cesión y bienes presentado por el secretario de Hacienda ${ }^{27}$. A pesar del parecer positivo que algunos liberales manifestaron días antes acerca del documento presentado, hubo un intenso debate acerca de la cesión de bienes. Así, el 21 de mayo, Canga Argüelles escribía:

reconozcan estos [el pueblo] el decidido ardor del rey en anticiparse a llevar por su parte a efecto las disposiciones del acta constitucional que libremente ha jurado; su noble desprendimiento, y el afán con que procura aumentar los fondos destinados al pago de los acreedores del Estado, cuya suerte le interesa altamente, y para cuyo alivio no dejará de acordar cuantas providencias pendan de su augusta autoridad, sin perjuicio de lo que las cortes acordasen en la materia, en uso de las facultades que les concede el art. 214 de la Constitución ${ }^{28}$.

Por su parte, Francisco Martínez Marina manifestaba su duda, ya que entendía que debían de ser las Cortes las que señalasen al monarca las posesiones que debía conservar. En la misma línea se manifestó Zapata, al señalar que la cesión no podía producirse al ser las Cortes las que debía de indicar las posesiones reales, por lo que "a nadie es permitido separarse un paso de su letra y su rigurosa observancia debe afianzar la sagrada libertad por la cual hemos hecho tantos sacrificios"29. Por el contrario, Martínez de la Rosa, en aras de la necesidad perentoria de la hacienda nacional, veía con buenos ojos no entrar en cuestiones constitucionales sobre la cesión y ser más pragmáticos ${ }^{30}$ y el conde de Toreno señalaba que "la comisión ha visto que se hacen reservas que tal vez no convienen con lo que prescribe la Constitución; pero que le ha parecido que no había inconveniente alguno en que se admitiese por ahora la cesión"31.

Con todo, el Decreto tras su discusión y conocimiento fue aprobado el 7 de agosto. Dos días más tarde se reconocía al monarca el derecho a ceder sus bienes, pero no a su reserva, que correspondía a las Cortes, lo que brindaba a la Corona una condición de propietario ${ }^{32}$, pasando la lista de fincas cedidas a la Junta Nacional del Crédito Público para su enajenación y venta.

El decreto de 9 de agosto indicaba, en el primer punto, que la Junta Nacional del Crédito Público era la que debía de proceder a la venta en subasta, conforme a las leyes,

25 Decreto de 30 de mayo, AGP, Reinados, Fernando VII, caja 330, exp. 1; E. García Monerris y C. García Monerris, Las cosas del rey..., p. 66.

26 Informe, AGP, Reinados, Fernando VII, caja 2, exp. 2.

27 Relación de bienes, AGP, AG, leg. 359.

28 Carta, AGP, Reinados, Fernando VII, caja 2, exp. 2.

29 Diario de las actas y discusiones de las Cortes. Legislatura de los años 1820 y 1821, Madrid, Imprenta especial de las Cortes, 1820, tomo II, pp. 178-179.

30 E. García Monerris y C. García Monerris, Las cosas del rey..., p. 67.

31 Diario de las actas y discusiones de las Cortes..., p. 178.

32 F. Cos-Gayón, Historia jurídica del Patrimonio Real, Madrid, Imprenta de Enrique de la Riva, 1881, p. 159. 
de todos los bienes que le fueron asignados por los decretos y reglamentos de 1813, 1815 y 1818, así como los de la extinguida Inquisición y los del decreto que separaba el patrimonio real de 30 de mayo de 1820 y los que las Cortes separasen en uso de la facultad que le confería el artículo 214 de la Constitución ${ }^{33}$.

En segundo lugar, recogía que para el pago de los bienes y fincas que se vendían serían admitidos los vales reales, recibos de intereses de estos, escrituras de capitales y cualquier especie de créditos por todo su valor con tal de que estuviesen liquidados y reconocidos; es decir, toda la deuda anterior y posterior al 18 de marzo de 1808; la cual, por el apartado quinto de la orden, debían de quemar. En el tercer punto se indicaba que no se admitirían cantidades en metálico, ni se reconocerían censos consignativos redimibles sobre la tercera parte del valor de las fincas por la tasación de que hablaba el artículo 24 del Decreto de las Cortes de 13 de septiembre de 1813 -que se revocaba-. En el cuarto punto del decreto se recogía que los bienes comprados no se podían vincular ni pasarlos a manos muertas. En sexto lugar se señalaba que dicho anuncio se realizaría con la suficiente anticipación para que se pudiesen hacer todas las reclamaciones. Por su parte, en el punto octavo, se refería que la Junta presentaría a las Cortes mensualmente un estado por provincias de las ventas y, en el punto décimo y último, se reconocía que se revocaban todos los decretos, órdenes e instrucciones anteriores en la parte que no estuviesen conformes con la orden ${ }^{34}$.

En aplicación del decreto, por ejemplo, el 24 de agosto de 1820, Juan Sánchez Godínez comunicaba al conde de Miranda que el secretario del Despacho de Hacienda le había informado que la Junta Nacional del Crédito Público había nombrado para la toma de posesión de los terrenos y demás efectos cedidos por el monarca en beneficio de la deuda pública a don Miguel Baguer para los sitios de Aranjuez, Acequia del Jarama, San Fernando, el Pardo y San Lorenzo; para el sitio de San Ildefonso a sus comisionados en Segovia; para Valladolid a don Luis Francisco de Luis y para Granada a don Francisco Escobar, a quienes se les dieron las órdenes convenientes por la citada Junta del Crédito Público.

Estos serían los encargados de llevar a buen puerto la nacionalización de estos bienes producida por la cesión "graciosa" de un soberano que iba por la senda constitucional ${ }^{35}$. En la misma carta, le indicaba que al tener los comisionados mucho trabajo en sus capitales sería posible que no pudiesen acudir personalmente, por lo que delegarían sus facultades en personas de toda confianza. Además, señalaba a Miranda que a la toma de posesión le acompañaría un agrimensor, para que al reconocer los terrenos y fijar los hitos o señales viese el medio o modo de distribuir en suertes o pequeñas porciones el conjunto con el fin de facilitar el mayor número de compradores, conforme a los deseos de las Cortes -lo que también respondía a cuestiones de los administradores de los sitios, aunque como veremos por otras razones. Finalmente, le indicaba que, tras tomar posesión, en unión con el perito que nombrase el procurador síndico general del municipio donde se hallase la finca, se realizaría la tasación de dichas posesiones, cuyos valores reunidos formarían el "total precio de la alhaja o posesión cedida"36.

Este proceso de nacionalización de parte del real patrimonio, como ocurrió décadas antes, vino acompañado por nuevos decretos que recuperaban la venta de bienes eclesiásticos o comunales para hacer frente a la deuda pública. Así, el 29 de junio de 1821,

33 Véase, P. Toboso Sánchez, "La Junta de Crédito Público en el Trienio Liberal", Revista de Estudios Políticos, 93 (1996), pp. 403-404. Decreto de 9 de agosto, AGP, AG, leg. 359.

34 Decreto, ibídem.

35 E. García Monerris y C. García Monerris, Las cosas del rey..., p. 71.

36

Memoria, AGP, AG, leg. 359. 
por ejemplo, se restablecía la venta de baldíos y bienes propios, recuperando así, el decreto de 4 de enero de $1813^{37}$, el primero de septiembre daba comienzo la venta de bienes de la Compañía de Jesús y el día 3 de dicho mes aparecía el decreto que reglamentaba el proceso de las fincas consignadas en el Crédito Público. Un mes más tarde, el primero de octubre de 1821, se procedería a la venta de bienes de órdenes religiosas ${ }^{38}$.

\section{LOS REALES SITIOS QUE SE CEDÍAN A LA NACIÓN}

De acuerdo con la información recabada por el mayordomo mayor y que se aprobó en las Cortes, la comisión anteriormente citada estableció, el 28 de abril, que la Corona se reservaba el Palacio Real y fincas colindantes, con las posesiones y lugares del Buen Retiro, el Casino, la Casa de Campo, la Moncloa y la Florida ${ }^{39}$. Además, en el heredamiento de Aranjuez se quedaba con el palacio, jardines, Casa del Labrador, Cortijo de San Isidro y los terrenos con las dehesas necesarias para la Real Yeguada, además de las casas de oficio y aposento imprescindibles para las jornadas y aposento de los empleados reales ${ }^{40}$. En esta elección se tuvo en consideración el recreo del monarca, así como la conservación del precioso arbolado del real Heredamiento. Sin embargo, se cedía a la Nación los tres quintos de la Dehesa de Villamejor y otros tantos de la de Mazarabuzaque, los terrenos de las acequias del Tajo y del Jarama, las fuentes y barcas, los molinos y venta de los puestos públicos, con las casas y edificios de dichas posesiones ${ }^{41}$.

El valor de los bienes que la Corona cedía a la Nación en este real sitio, de acuerdo con la relación remitida el 5 de septiembre de 1820 por el administrador don Manuel de Alvear, (véase tabla 1) era de 1.126.920 reales de vellón; si bien, estos tenían unos gastos y cargas que sumaban 743.624 reales y 14 maravedíes, por lo que se dejaría un sobrante de 383.295 reales y 20 maravedíes que se destinarían al mantenimiento del ayuntamiento constitucional. Así, en dicho mes de septiembre, dos regidores de Aranjuez solicitaron a Manuel de Alvear las relaciones de todos los oficiales que estaban ahora a sus órdenes, así como los sueldos y emolumentos que disfrutaban ${ }^{42}$. Ahora bien, en la Memoria que la Comisión de la Junta Nacional de Crédito Público presentó a las Cortes, en marzo de 1822, se indicaba, en su apartado tercero, que: "Las fincas que se adjudican con cargas, como el Real Sitio de Aranjuez y las acequias del Jarama, con unos gastos que superaban su producto" 43 .

37 F. Tomás y Valiente, El marco político de la desamortización en España, Barcelona, Ariel, 1972, pp. 12-37 y 68.

38 R. Herr, "El significado de la desamortización en España", Moneda y Crédito, 131, (1974), pp. 57-94 y Brines Blasco, J. "Deuda y desamortización durante el Trienio Liberal", Moneda y Crédito, 124, (1973), pp. 51-67.

39 F. Díez Moreno, "La evolución constitucional del patrimonio nacional", Reales Sitios, núm. extra 1, (1989), p. 19.

40 Memoria, AGP, AG, leg. 359.

41 El 11 de julio se hacía entrega a los comisionados en la provincia de Madrid y de Toledo por la Junta de Crédito Público, don Miguel Baguer y don Francisco Pérez, de la real acequia del Jarama. Memoria, AGP, AG, leg. 359 y Reinados, Fernando VII, caja 2, exp. 2.

42 Petición de información. AGP, AG, leg. 359.

43 P. Toboso Sánchez, "La Junta del Crédito Público...", p. 410. 
Tabla 1. Valor de los bienes que se cedían a la nación y suma de los gastos de Aranjuez

\begin{tabular}{|c|c|}
\hline BIENES E INGRESOS & $\begin{array}{l}\text { Reales de } \\
\text { vellón }\end{array}$ \\
\hline $\begin{array}{c}3 \text { quintos de la dehesa de Mazarabuzaque y otros tres de } \\
\text { Villamejor }\end{array}$ & 226.000 \\
\hline Beneficios de grano y ganado de ambas dehesas & 115.000 \\
\hline Por aprovechamiento de leñas de dichas dehesas & 5.000 \\
\hline El Soto y Molinos de Valdajos & 36.000 \\
\hline La Acequia del Tajo por todos sus productos de diezmos y rentas & 136.000 \\
\hline $\begin{array}{c}\text { Derechos de los puentes de la Calzada que pasaron a la } \\
\text { Dirección de Correos }\end{array}$ & 260.000 \\
\hline Puente de Aceca y barca de la Reina & 15.800 \\
\hline $\begin{array}{l}\text { Renta anual que se consideraba hasta reintegrar a los } \\
\text { empresarios en la construcción de los molinos de la Aceca }\end{array}$ & 34.000 \\
\hline Productos de puestos públicos y ramos arrendables & 190.000 \\
\hline Producto de parte del Soto Redondo & 820 \\
\hline De las bóvedas arruinadas del Palacio de Aceca & 1.600 \\
\hline Alquileres de las oficinas de los puestos públicos & 14.000 \\
\hline Pozos de nieve & 5.000 \\
\hline Por la tahona & 6.600 \\
\hline Arriendo de tejares & 2.000 \\
\hline Casa de Conejos de las dehesas de Mazarabuzaque y Villamejor & 6.000 \\
\hline Alquiler de una fragua & 1.500 \\
\hline Penas de cámara & 1.100 \\
\hline $\begin{array}{l}\text { Pensiones que disfrutaba el Hospital de San Carlos sobre varios } \\
\text { fondos píos }\end{array}$ & 70.000 \\
\hline Producto de tierras de los manantiales de aguas dulces & 500 \\
\hline TOTAL & 1.126 .920 \\
\hline \multicolumn{2}{|l|}{$\begin{array}{c}\text { CARGAS Y GASTOS DE LOS ESTABLECIMIENTOS } \\
\text { PÚBLICOS CEDIDOS }\end{array}$} \\
\hline $\begin{array}{c}\text { Gastos del juzgado y policía, según lo pagado desde el } \\
\text { primero de enero de } 1816 \text { hasta fin de julio de } 1820 \text { sin meter } \\
\text { las cantidades que se estampaban como presupuestos fijos } \\
\text { atendiendo a que podían variar }\end{array}$ & 13.000 \\
\hline Sueldos de los empleados que fueron del gobierno y juzgado & 126.430 \\
\hline
\end{tabular}




\begin{tabular}{|c|c|}
\hline $\begin{array}{l}\text { Jubilaciones, viudedades, orfandades y pensiones } \\
\text { correspondientes al ramo del Gobierno y Justicia }\end{array}$ & 64.291 y 46 \\
\hline \multicolumn{2}{|l|}{ PARROQUIA DE ALPAJÉS } \\
\hline Gastos para el culto & 11.000 \\
\hline Sueldos de sus empleados & 38.280 \\
\hline Jubilaciones, viudedades y orfandades & 4.990 \\
\hline \multicolumn{2}{|l|}{ EDUCACIÓN PÚBLICA } \\
\hline \multicolumn{2}{|l|}{ Empleados } \\
\hline Don Nicolás Vieites, maestro de primeras letras & 3.650 \\
\hline Don Manuel Marcos Chinchón, maestro de primeras letras & 3.300 \\
\hline Don Antonio Marcos Chinchón, ayudante & 2.555 \\
\hline Doña Gervasia María Bachiller, maestra de niñas & 2.190 \\
\hline Doña Rosa Delgado, ayudanta & 1.460 \\
\hline Viudedades y orfandades & 2.920 \\
\hline \multicolumn{2}{|l|}{ FUENTES DE AGUA DULCE } \\
\hline Gastos & 12.000 \\
\hline Empleados & 21.330 \\
\hline Jubilaciones, viudedades y orfandad & 6.745 \\
\hline \multicolumn{2}{|l|}{ HOSPITAL } \\
\hline \multicolumn{2}{|l|}{$\begin{array}{l}\text { Gastos (no está del todo corriente ya que no se ha podido } \\
\text { recaudar la pensión de } 70.000 \text { que disfruta sobre diferentes } \\
\text { fondos píos, por lo que no se le señala gasto alguno) }\end{array}$} \\
\hline Empleos & 37.670 \\
\hline Jubilaciones, viudedades y orfandades & 7.604 y 5 \\
\hline \multicolumn{2}{|l|}{ MEDICINA, CIRUGÍA Y OBSTETRICIA } \\
\hline Empleos & 43.590 \\
\hline Jubilaciones, viudedades y orfandades & 22.173 y 6 \\
\hline \multicolumn{2}{|l|}{ OBRAS CIVILES } \\
\hline Empleos & 25.955 \\
\hline Jubilaciones, viudedades y orfandades & 16.438 y 10 \\
\hline \multicolumn{2}{|l|}{ BOTICA } \\
\hline Empleos & 8.800 \\
\hline Jubilaciones, viudedades y orfandades & 7.665 \\
\hline
\end{tabular}




\begin{tabular}{|c|c|}
\hline ACEQUIA DEL TAJO & \\
\hline Gastos & 14.840 \\
\hline Empleados & 15.750 \\
\hline Consignaciones de cebada & $\begin{array}{c}45 \text { fanegas } \\
\text { para el guarda } \\
\text { mayor y } 30 \\
\text { para cada uno } \\
\text { de los tres } \\
\text { guardas y el } \\
\text { ayudante }\end{array}$ \\
\hline \multicolumn{2}{|l|}{ ORATORIO } \\
\hline Don Julián Corcovado, capellán & 2.700 \\
\hline $\begin{array}{l}\text { La dignidad arzobispal de Toledo gozaba anualmente por los } \\
\text { derechos que le pertenecían, de acuerdo con la concordia } \\
\text { celebrada el } 13 \text { de julio de } 1587\end{array}$ & $\begin{array}{c}1.323 \text { y } 18 \text { y } \\
365 \text { fanegas } \\
\text { de trigo y } 65 \\
\text { de cebada }\end{array}$ \\
\hline Viudedades & 912 у 17 \\
\hline $\begin{array}{c}\text { JUBILACIONES Y VIUDEDADES DE LOS OFICIALES QUE } \\
\text { SIRVIERON EN LA PLAZA DE TOROS }\end{array}$ & 9.320 y 17 \\
\hline \multicolumn{2}{|l|}{ DEHESA Y MOLINOS DE VALDAJOS } \\
\hline Gastos & No se indican \\
\hline Oratorio & 2.700 \\
\hline \multicolumn{2}{|l|}{$\begin{array}{c}\text { TRES QUINTOS DE MAZABUZAQUE Y LOS TRES DE } \\
\text { VILLAMEJOR }\end{array}$} \\
\hline Guarda y custodia & 36.160 \\
\hline Jubilaciones y viudedades & 36.476 у 33 \\
\hline Cargas & 87.659 y 8 \\
\hline $\begin{array}{c}\text { MOLINOS Y PUENTE DE ACECA (JUBILACIONES, } \\
\text { VIUDEDADES Y CARGAS) }\end{array}$ & 15.038 у 24 \\
\hline \multicolumn{2}{|l|}{ PUENTES } \\
\hline Gastos de conservación y reparación & No se indican \\
\hline Empelados & 31.450 \\
\hline Viudedades y orfandad & 2.550 \\
\hline TOTAL & $\begin{array}{c}743.624 \text { reales } \\
\text { y } 14 \mathrm{mrs}\end{array}$ \\
\hline
\end{tabular}

Fuente: Inventario. AGP. AG, leg. 359. 
Por su parte, de acuerdo con el inventario de bienes remitido a las Cortes (véase tabla 2), Fernando VII se reservaba el palacio de EI Pardo, todos sus jardines, la Casa del Príncipe, monte y Quinta del duque del Arco y la Zarzuela, con las casas de oficio y aposento y las necesarias para los empleados. Se procedía a ceder a la Nación los puestos públicos de la abacería, mercería, aguardientería, mesón y bodega, venta de sal, casa donde se pesaba el grano, tahona, escuelas, el hospital con seis camas y todo lo necesario, el matadero y la taberna, así como el jardincillo que fue del infante don Gabriel y que estaba destinado a la construcción de un cementerio, además del monte titulado de la Moraleja, con sus edificios. El total de bienes cedidos según la tasación realizada por Lorenzo Gómez, el 14 de agosto de 1820 , sumaba casi 1.700 .000 reales de vellón, los cuales tenían 80.000 reales de cargas en concepto de salarios, viudedades y $\operatorname{reparos}^{44}$.

La persona encargada por parte de la Junta Nacional del Crédito Público para tomar posesión de estos bienes cedidos fue don José Trigo de Marta; si bien, el 6 de octubre de 1821 el contador de El Pardo indicaba que todavía no se había realizado la enajenación y que solo el Ayuntamiento de El Pardo se había hecho cargo de los puestos públicos y casa de abasto.

Tabla 2. Valor de los bienes que se cedían a la nación y suma de los gastos en El Pardo

\begin{tabular}{|c|c|}
\hline & $\begin{array}{c}\text { Tasación (reales } \\
\text { de vellón) }\end{array}$ \\
\hline El monte de la Moraleja & 1.198 .950 \\
\hline Palacio de la Moraleja & 433.362 \\
\hline \multicolumn{2}{|l|}{ PUESTOS PÚBLICOS EN EL PARDO } \\
\hline Abacería & 3.750 \\
\hline Mercería & 2.295 \\
\hline Aguardentería & 9.020 \\
\hline Mesón y bodegón & 5.200 \\
\hline Venta de sal & 420 \\
\hline Medición de granos & 400 \\
\hline Taberna & 9.000 \\
\hline Tahona & 5.200 \\
\hline Hospital & - \\
\hline Matadero & - \\
\hline Escuelas & - \\
\hline 4 almacenes & - \\
\hline
\end{tabular}




\begin{tabular}{|c|c|}
\hline IMPOSICIONES & \\
\hline Cuarto en cada libra de carne & 9.952 \\
\hline $\begin{array}{l}\text { Imposición de un cuarto en el cuarto del vino que tenía la } \\
\text { taberna }\end{array}$ & 9.000 \\
\hline $\begin{array}{l}\text { Imposición de los edificios correspondientes para estos } \\
\text { abastos }\end{array}$ & 9.000 \\
\hline TOTAL & 1.695 .549 \\
\hline \multicolumn{2}{|l|}{ CARGAS DEL MONTE DE LA MORALEJA } \\
\hline 1 sobreguarda y 3 guardas & 13.855 \\
\hline \multicolumn{2}{|l|}{ CULTO PÚBLICO } \\
\hline \multicolumn{2}{|l|}{$\begin{array}{l}\text { La capilla del real sitio tenía a su cargo la cura de almas } \\
\text { y era la parroquia del mismo lugar. Para su dotación } \\
\text { consignó el monarca una pensión de } 3.823 \text { reales y } 18 \\
\text { mrs sobre el sello de la cera de Castilla, que cesó por el } \\
\text { nuevo sistema, y otra de } 22.000 \text { reales sobre la mitra de } \\
\text { Palencia }\end{array}$} \\
\hline $\begin{array}{l}1 \text { primer capellán, } 1 \text { capellán auxiliar, } 1 \text { presbítero } \\
\text { sacristán, } 1 \text { ayuda del sacristán y } 1 \text { monaguillo }\end{array}$ & 21.245 \\
\hline HOSPITAL & \\
\hline \multicolumn{2}{|l|}{$\begin{array}{c}\text { Correspondiendo este edificio al crédito público deberá de } \\
\text { ser de su cuenta el pago de los empleados o sujetarse a } \\
\text { las decisiones generales adoptadas o que se adopten en } \\
\text { el asunto. Los empleados y sus sueldos eran }\end{array}$} \\
\hline $\begin{array}{c}1 \text { administrador del hospital, } 1 \text { practicante, } 1 \text { mozo, } 1 \\
\text { enfermera, } 1 \text { enfermera jubilada }\end{array}$ & 73.891 \\
\hline 1 médico, 1 cirujano, botica & 23.100 \\
\hline \multicolumn{2}{|l|}{ EDUCACIÓN PÚBLICA } \\
\hline Don José Lucio García, maestro de primeras letras & 5.475 \\
\hline Doña Teresa González, maestra de niñas & 2.190 \\
\hline $\begin{array}{c}\text { La facultad de medicina y cirugía debían de ser de libre } \\
\text { elección del pueblo y pagarse de sus fondos. Si fuesen } \\
\text { elegidos por el Ayuntamiento éste les debería de pagar, } \\
\text { correspondiendo al monarca lo que sea por la asistencia } \\
\text { que hagan a sus criados. Los sueldos de los actuales } \\
\text { eran: }\end{array}$ & \\
\hline
\end{tabular}

Fuente: Inventario. AGP. AG, leg. 359. 
En cuanto al real sitio de San Fernando, se reservaba al monarca la posesión de San Fernando, así como los Sotos de Aldovea, Torrejón, parte de los de Galapagar y Quintana, el Castillo de Aldovea y su huerta — todos con sus arbolados_, además de las tierras de pan ubicadas en Daralcalde, Viveros, Matilla de Mejorada, Vaciabotas, el Soto de Bollero y Baezuela, que se hallaban pobladas y acotadas, - muchas de las cuales se habían incorporado al patrimonio real entre 1803 y $1805^{45}$.

Tabla 3. Estado de las cesiones y valor en San Fernando

\begin{tabular}{|c|c|c|c|c|c|}
\hline & $\begin{array}{c}\text { Suerte } \\
\text { de } \\
\text { tierras }\end{array}$ & Fanegas & Celemines & Estadales & $\begin{array}{c}\text { Valor (reales } \\
\text { de vellón) }\end{array}$ \\
\hline Despoblado de Viveros & 26 & 558 & 0 & 29 & 418.361 y 23 \\
\hline Daralcalde & 4 & 94 & 2 & 19 & 74.437 y 9 \\
\hline Quintana & 15 & 484 & 7 & 12 & 141.540 y 21 \\
\hline Vaciabotas & 14 & 369 & 10 & 1 & 123.794 y 9 \\
\hline Galapagar & 8 & 188 & 2 & 0 & 107.126 y 18 \\
\hline Horno de Isidro & 1 & 17 & 7 & 27 & 7.761 y 9 \\
\hline Estado del Bollero & 1 & 66 & 5 & 20 & 19.940 \\
\hline Matilla de Mejorada & 1 & 19 & 9 & 0 & 1.497 y 17 \\
\hline Idem & 1 & 12 & 2 & 2 & 10.738 y 25 \\
\hline Total & 71 & 1810 & 11 & 10 & 905.197 y 29 \\
\hline Baezuela & & 777 & 6 & 16 & \\
\hline Total & & 2588 & 5 & 27 & \\
\hline
\end{tabular}

Fuente: Gaceta de Madrid, núm. 150, p. 660.

El administrador del real sitio, antes de proceder a la entrega, planteó a la mayordomía dos dudas. La primera, se refería a la cesión o no de los diezmos de las tierras de pan que se daban a la Nación y, en segundo lugar, si también daba al Crédito Público el pie de agua que disfrutaban dos tierras de 18 fanegas del término de Viveros. Obteniendo en ambos, desde palacio, una respuesta positiva ${ }^{46}$. El 3 de octubre de 1820 Patricio Peloyo certificaba que el comisionado de la Junta Nacional de Crédito Público, don Miguel Baguer, había tomado

45 Compras, AGP, Administración Patrimonial (en adelante AP), San Fernando, caja 10.138, exp. 1. Memoria de Baezuela, AGP, AG, leg. 359. Aparece en una relación de 3 de octubre de 1820 hecha por Patricio del Oto. El 5 de septiembre de 1820 tomó posesión Miguel Baguer.

46 Petición de información, AGP, AG, leg. 35. 
posesión de las tierras cedidas. Poco después, el 5 de octubre, don Bernardino de Temes y don Antonio Barata, en nombre de la Junta Nacional, solicitaron a la mayordomía mayor los títulos de propiedad de todos los bienes concedidos a la nación para evitar problemas a los futuros compradores (parece que la transmisión de información por parte de la mayordomía y de los oficiales de los sitios a la comisión de Crédito no fue fluida).

En San Ildefonso, por su parte, se reservaba para el rey el palacio y jardines, así como las casas de oficio y aposento y las necesarias para los empleados, además de los palacios de Valsaín y de Riofrío, pasándose a la Junta Nacional del Crédito Público todo lo demás, con inclusión de los pinares y puestos públicos ${ }^{47}$. En la cesión entraban las fincas reales denominadas el Parque y el Bosquecillo, la cual tenía una casa, denominada "de la Hierba" y un cercado para el ganado, así como, la Mata de la Sauca, diferentes matas robledales que se compraron a las Comunidades de Ciudad y Tierra de Segovia y su Junta de Linajes, por escritura de 4 de octubre de 1771, la huerta del Hospital y la huerta del Venado, la Dehesa de la Nava del Rincón, acotada y vedada por real orden de 9 de agosto de 1778, cuyos pastos de verano disfrutaba el ganado trashumante de la cabaña que fue del infante don Carlos; el cerro de Matabueyes, que fue cercado de pared en seco en virtud de la real orden de 11 de octubre de 1806; además del huerto de Valsaín y el monte de Riofrío, que fue comprado por reales órdenes de 24 de marzo de 1740 y 19 de julio de 1751 al marqués de Paredes. Asimismo, la Nación recibió cinco tierras de pan que tenía en arriendo Benito Fernández en el lugar nombrado la Lastra o Bote de la Encina Alta, la Dehesa de Aldeanueva con una casa de esquileo y la Mata de Pirón, comprada en 1761 a las Comunidades de Ciudad y Tierra de Segovia y su Junta de Linajes, así como el pinar de la villa de Coca, que fue incorporado al real patrimonio el 25 de julio de $1804^{48}$.

En virtud de los espacios y bienes cedidos a la Junta Nacional, el 8 de agosto de 1820, el contador interino del sitio, don Juan Sánchez Godínez, realizó nuevas listas aclaratorias en donde recogía los empleados y demás obligaciones que pasaban a cargo de la nación y los que debían quedar en los palacios, jardines y demás casas a cargo del presupuesto del rey. De acuerdo con la misma, la nación debía de hacerse cargo de 470.361 reales de vellón y 58 maravedíes y medio por el pago de los salarios de los oficiales, mientras que la Tesorería de la Real Casa tendría que seguir abonando en salarios y pensiones 405.301 reales y 8 maravedíes ${ }^{49}$.

Asimismo, en la misma relación, Juan Sánchez Godínez indicaba el coste de las pensiones, viudedades, orfandades y jubilaciones que había en San Ildefonso y que las percibían en virtud de reales órdenes por la Tesorería de la Real Casa; si bien, en adelante, en muchos casos debían de pasar a la Nación ${ }^{50}$. Así, la hacienda del rey debía de hacer frente, anualmente, al pago de 99.213 reales de vellón y 8 maravedíes y medio, mientras que la hacienda estatal debía de asumir 65.148 reales y 25 maravedíes, sobre todo, por las pensiones a viudas y huérfanos de los guardas de los pinares.

Hasta el 29 de agosto de 1820 el administrador del sitio no recibió del mayordomo mayor la orden para proceder a la entrega de los citados bienes a la comisión del Crédito Público. Por ello, el 31 de agosto, el contador don Juan Sánchez Godínez y don Pedro López de Orozco y Orozco, guarda mayor de los reales bosques, así como los comisionados principales del Crédito Público en la provincia de Segovia, don Juan de Mata y Torre y Manuel

47 Memoria, AGP, AG, leg. 359.

48 Memoria, ibídem.

49 Se indicaba que los oficiales que quedaban a cargo de la tesorería de la casa recibiesen un nuevo reglamento. Memoria de los oficiales y sueldos, ibíd. En las tablas siguientes faltan algunos oficios y sueldos.

50 Todos disfrutaban de médico, cirujano, botica, bula y casa. Relación, ibídem. 
Fernández, escribano del real sitio, comenzaron a formalizar el proceso de cesión, tomando posesión los dos últimos de las fincas reales denominadas el Parque y el Bosquecillo, que fueron cercadas por la Corona en virtud de reales órdenes de 28 de noviembre de 1728 , de 29 de septiembre de 1734, de 31 de mayo de 1769 y de 8 de diciembre de $1784^{51}$. Un día más tarde, por señalar otro ejemplo, la comisión tomaba posesión de la Mata de la Sauca, acotada y vedada en virtud de la real orden de 29 de febrero de 1756, así como de la huerta del Hospital de San Fernando, que pertenecía al rey por compra que hizo al duque de Arión ${ }^{52}$.

Como ocurría en otros reales sitios, el proceso de cesión a los miembros de la comisión de la Junta de Crédito Público no fue fácil. Los oficiales reales trataron de dilatar el proceso, reclamando a palacio más información, planteando dudas sobre la ejecución de las órdenes. El contador interino del sitio ponía trabas a la cesión, requiriendo, por ejemplo, a la comisión la presencia del agrimensor, tal y como se desprende de una carta de don Ramón Calvo, consultor de la real casa, al mayordomo mayor, de 15 de septiembre, en donde le indicaba que le escribiese para que no se opusiese y que no diese "margen con ellas a que se crea que el ánimo del Rey y de V.E. es poner trabas a la cesión después de aprobada por las Cortes; y acaso sería conveniente trasladarlo al Sr. secretario el Despacho de Hacienda para que se convenciese del recto modo con que V.E. procede"53. En el caso de los pinares de Valsaín y Riofrío, por señalar otro ejemplo, el contador solicitó a la comisión que se mantuviesen el guarda mayor y varios dependientes en su guarda y conservación, ya que, dada la extensión y dificultad del terreno, se esperaba que se tardase mucho en tasarlo.

Otro elemento importante, como ya ocurrió con San Fernando, es que el ministerio de Hacienda solicitaba a palacio la remisión de todos los títulos de propiedad de los lugares cedidos para evitar a los futuros compradores problemas y juicios. En este sentido, Canga Argüelles, el 26 de noviembre, escribía al mayordomo mayor para reclamarle los títulos y derechos que había sobre los bienes cedidos de Valsaín, Riofrío y San Ildefonso, para así evitar que el ayuntamiento y procuradores de la ciudad de Segovia reclamasen derechos que no tenían ${ }^{54}$. Parece que los requerimientos desde Hacienda no surtían los resultados esperados, a pesar de que don Ramón de Carranza, escribano de la extinguida Junta Patrimonial, fue encargado de remitir desde palacio los títulos de propiedad de todos los bienes cedidos a la nación y de tratar estas cuestiones con la persona propuesta por parte de la Junta Nacional que fue don Joaquín Cidiel Fernández, oficial de la contaduría principal de la citada Junta ${ }^{55}$.

Cuando el duque de Montemar, don Antonio Ponce de León y Dávila, que ocupó el lugar del conde de Miranda, como mayordomo mayor del rey por decreto de 18 de noviembre de $1820^{56}$, indicaba el 6 de diciembre que ya se había procedido a la posesión por parte de la comisión del Crédito Público de las tierras y bienes cedidos, el ministerio se quejaba, todavía, de la falta de títulos y documentos de propiedad ${ }^{57}$. En este sentido, el 20 de septiembre de 1821, Juan Sánchez Godínez enviaba al mayordomo mayor una serie de títulos ${ }^{58}$.

51 Tomas de posesión, ibídem.

52 Posesión, ibídem.

53 Carta, ibídem.

54 Carta, ibídem.

55 Carta de 4 de noviembre de 1820 de Antonio Barata y Bernardino de Lemes al mayordomo mayor, ibídem.

56 Expediente personal. AGP, Personal, caja 697, exp. 30.

57 Informe, AGP, AG, leg. 359.

58 Memoria de títulos, ibídem. 
Por su parte, la Corona mantenía el palacio-monasterio de San Lorenzo de El Escorial, el jardín, las dos casas de campo, las casas de oficios, aposento y las necesarias para los empleados, cediéndose las demás pertenencias y derechos de dicho real sitio a la deuda pública. Entre lo que se enajenaba estaba la abadía de Santa María de Párraces y sus bienes, así como el Soto de Piul, que tenía 1.235 fanegas y 365 estadales, el Soto del Palancar, de 149 fanegas y 167 estadales, y el Soto del Arenal de 122 fanegas y 333 estadales. Poco después, el 12 de agosto, se remitían por parte del conserje las cargas y obligaciones que debían de gravitar sobre el real sitio de acuerdo con la cesión ${ }^{59}$.

En Sevilla, por su parte, permanecían dentro del patrimonio de la Corona los alcázares y jardines, así como la Casa de la Contratación (que había sido usaba por el Consulado sin pagar nada), la huerta del Retiro y la de la Alcoba, así como las diferentes edificaciones que se encontraban dentro del recinto actual del Alcázar. Mientras que se cedían los demás edificios y pertenencias, incluso el Lomo del Grullo, tomando posesión el Crédito Público el 29 de julio de este espacio de 32.000 fanegas que llevaba desde 1818 cedido en enfiteusis. El conde de Toreno fue un firme defensor de la cesión de este espacio singular ya que consideraba que era el lugar idóneo para cumplir la promesa de tierras que se hizo a los jefes del primer ejército de San Fernando ${ }^{60}$, procediéndose a su venta en lotes, conforme al artículo 18 del Decreto de 13 de setiembre de 1813.

En Valladolid quedarían para la Corona el palacio y el jardín con su huerta y se daba al estado los demás edificios y huertas ${ }^{61}$. Por su parte, la Caballeriza de Córdoba también se cedía a la Nación para el beneficio del Crédito Público, trasladándose los caballos que quedaban a Aranjuez. El 30 de agosto el funcionario del crédito público tomaba posesión de las dehesas vinculadas a la real caballeriza y que suponían la cesión de unas 4.500 fanegas de tierra ${ }^{62}$. Asimismo, en Córdoba también se cedieron diversas casas, las cuales, se sacaron a pública subasta los días 12 y 14 de febrero de 1821. Podemos citar entre las mismas la que estaba en la calle del Pozo número 5, por 10.495 reales, y el acebuchal titulado Pendolillas de 119 fanegas y 10 celemines de tierra con 1.895 olivos y diversas casas por 466.812 reales $^{63}$.

En Granada se reservaba el monarca la Alhambra con sus jardines y se cedía todo lo demás en "alivio de sus amados súbditos ha tenido a bien ceder para el pago de la deuda pública"64. El gobernador de la Alhambra, el 20 de junio, informaba al mayordomo mayor del interés de algunos de los bienes que podían perderse y que se tendrían que mantener, como las alamedas que había de acceso a la Alhambra, que servían al recreo, así como la acequia llamada del Rey, que surtía de agua a los jardines y palacios, puesto que sin ella no se podía mantener el sitio. En esta misma línea, el 29 de julio, pedía información al mayordomo mayor sobre qué hacer con algunas posesiones, como el fuerte llamado la Alcaicería o los que había en Montefrío, illora, Moclín, Iznallor, Piñar, Cuesta de la Cevada, la Pera, Tajarja y el Salar, así como una casa real que había en la ciudad de Santa Fe, así como las puertas de Elvira, el Pescado y de los Molinos, ya que no quedaba claro si debían permanecer en manos del real patrimonio o darse a la deuda pública. El gobernador

59 Memoria, ibíd. Asimismo, A. Madruga Real, "El Escorial a debate. Informes, discusiones y propuestas en las Cortes del siglo XIX", Anales de Historia del Arte, 11, (2001), pp. 294-295.

60 Diario de las actas y discusiones de las Cortes..., p. 176.

61 Memoria, AGP, Reinados, Fernando VII, caja 2, exp. 2; F. Díez Moreno, "La evolución constitucional...", pp. 19-20.

62 Informe, AGP, Reinados, Fernando VII, caja 276, exp. 9.

63 Gaceta de Madrid..., núm. 104, p. 508.

64 Memoria, AGP, AG, leg. 359. 
manifestaba en sus escritos que, a pesar de no tener mucho valor económico, estos lugares sí tenían interés para el decoro y defensa del reino, por lo que debían permanecer en el patrimonio real. Como advirtió el conde de Miranda años antes, el 31 de mayo de 1820, al ministro de Hacienda, estos bienes que el monarca había cedido "por su naturaleza vincular, solo le correspondía el usufructo; porque nadie de otro modo se prepara a defender los derechos que tiene en lo que voluntariamente ha cedido"65.

\section{BIENES NACIONALIZADOS Y REFORMA EN LA GESTIÓN DEL REAL PATRIMONIO}

La cesión de bienes por parte de la Corona no era despreciable y podía suponer una gran ayuda para consumir la deuda que mantenía el Estado, que superaba los 900 millones de reales. Entre 1811 y 1811 la deuda creció a un ritmo de 7’8 \% anual66. En una relación posterior se indicaba que la valoración de los bienes cedidos por el rey ascendía a unos 80 millones de reales. La cantidad, ya de por si importante - superaba a todos los ingresos de la nación, salvo la contribución directa y el derecho de los puertos, de acuerdo con el informe presentado en las Cortes por Canga Argüelles en $1820 \_{ }^{67}$, suponía un alivio para una hacienda que estaba al borde de la bancarrota.

Estos ingresos y el alivio en los gastos, al verse recortado las cantidades necesarias por parte de la Corona para el mantenimiento de su real patrimonio, estarían dentro de la línea económica diseñada por el ministro Canga, el cual trataba de recuperar el sistema hacendístico gaditano y de imponer por parte del Estado un control sobre el conjunto del patrimonio ${ }^{68}$. Canga Argüelles impulsó esta política de cesión a la Junta Nacional de Crédito Público, la cual, de acuerdo con la memoria presentada a las Cortes en 1820, contaba con unos arbitrios que no superaban los 82 millones de reales; lo que no servía para el pago de los intereses anuales, que sumaban 156,8 millones de reales ${ }^{69}$, y el patrimonio real sería un elemento central de la política hacendística y crediticia de la Nación ${ }^{70}$.

Ahora bien, si no se procedía a la rápida toma de posesión por parte de la Junta de Crédito y a su posterior subasta se corría el riesgo, como así ocurrió, de que estos lugares fuesen saqueados como, por ejemplo, con los bienes cedidos en Aranjuez, aprovechando que los nuevos gestores carecían de medios para su control y guarda ${ }^{71}$.

Las subastas llevadas a cabo por la Junta del Crédito Público se hicieron más comunes en 1821 y 1822 . En este sentido, el 30 de enero, se procedió a la venta de los pinares y matas de Valsaín, Picón y Riofrío72; el 26 de marzo de 1822, como recogía el Diario de Madrid, el marqués de Pontejos adquirió en pública subasta realizada en el juzgado

65 T. Cortina, Memoria que con motivo del dictamen de la comisión del Congreso de Sres. Diputados sobre Abolición del Real Patrimonio en la Antigua Corona de Aragón presenta al Excmo. Sr. Tutor de S.M. la Reina Doña Isabel II el consultor general de la Real Casa, Madrid, Aguado. Impresor de Cámara de S.M., 1842, p. 56.

66 J. Canga Argüelles, Memoria sobre el crédito público que presenta á los Córtes ordinarias de 1820 Don José Canga-Argüelles, Secretario de Estado, y del Depache universal de Hacienda de España y Ultramar, Madrid, Imprenta García, 1820, pp. 47-52. Disponible en: http://mdz-nbn-resolving.de/urn:nbn:de:bvb:12bsb10362485-2 (Consultado el 4 de enero de 2020)

67 Diario de las Sesiones de las Cortes, ACD, 13 de julio de 1820, apéndice al número 9, vol. 3, p. 89. Disponible en https://app.congreso.es/est_sesiones/ (Consultado el 20 de noviembre de 2019).

68 Ibídem, pp. 79-122; E. García Monerris y C. García Monerris, La bolsa del rey..., p. 71.

69 P. Toboso Sánchez, "La Junta de Crédito Público..., p. 402.

70 J. Canga Argüelles, Memoria sobre el crédito...

71 Informe, AGP, AP, Aranjuez, caja 14.299.

72 Memoria, AGP, AG, leg. 359. 
de primera instancia de Alcalá de Henares, los Sotos de Piul, Palancar y del Arenal, que pertenecían al Escorial, por 1.780.584 reales y 17 maravedíes y, el 20 de agosto de 1822, se procedió a la venta del monte de la Moraleja ${ }^{73}$. Con todo, algunos diputados no estaban contentos con la celeridad en el proceso. Así, a comienzos de marzo de 1822, se solicitó la formación de una nueva comisión que tratase sobre la enajenación del patrimonio real. Se demandaba, de nuevo, que fuesen las Cortes las que sancionasen los espacios reservados al monarca y no la Corona ${ }^{74}$.

La cesión de una parte significativa del real patrimonio también tendría consecuencias en la gestión y conservación del que quedaba reservado para el monarca. Así, por ejemplo, por orden de 6 de junio de 1820 la Compañía de Guardabosques, a su pesar, dejaría de depender del monarca y pasaría al Cuerpo General del Ejército, bajo el control del ministerio de la Guerra ${ }^{75}$. También se llevarían a cabo reformas en la mayordomía mayor, gestora, en última instancia del patrimonio. Esta misión recayó en el IV duque de Montemar, mayordomo mayor desde el 18 de noviembre de 1820 en lugar del conde de Miranda, hombre de la máxima confianza de Fernando $\mathrm{VII}^{76}$, que fue defenestrado por los liberales en el proceso de depuración de los principales cargos de la casa, a pesar de que, desde el 11 de marzo, se había manifestado por adaptar la administración de la casa a la nueva legalidad constitucional ${ }^{77}$.

Montemar tras tomar posesión de su nuevo cargo intentó realizar un reglamento para el gobierno de las posesiones reales y de palacio. En este sentido, el 20 de junio de 1821, escribía al monarca indicándole, entre otras cuestiones, que no había encontrado unas instrucciones o reglamento particular para el gobierno y administración del patrimonio real y que era muy importante hacer uno debido a la situación económica ${ }^{78}$.

Justificaba, así, ante Fernando VII, la necesidad de dicho reglamento, no sólo para el decoro de la figura real y su familia, sino para hacer frente a las necesidades de las "4.500 familias que entre criados, viudas y huérfanos lo reciben de las Augustas Manos de V.M., objetos todos caros a su magnánimo y beneficio Corazón"79. Por lo que era necesario realizar una instrucción general para todos los administradores de los reales sitios en donde se indicasen sus respectivas atribuciones, cargos y responsabilidades, dotaciones, número de dependientes, seguridades en el manejo de caudales, efectos, etc., más aún, en este periodo de cambios.

Para ello, solicitó al contador, veedor, tesorero, conserjes y administradores de los reales sitios toda la información de sus respectivos ramos y de sus cargas, además de las propuestas de reformas y reducción del gasto que tenían o que se les hubiesen hecho. De acuerdo con los principios que prometió al jurar su cargo: orden, claridad y economía, se

73 Informe, AGP, Reinados. Fernando VII, caja 16, exp. 16.

74 A.M. Moral Roncal, "La real casa y patrimonio en el reinado de Fernando VII (1814-1833)", en R. Sánchez y D. San Narciso (coords.), La cuestión de palacio. Corte y cortesanos en la España contemporánea, Granada, Comares, 2018, p. 179.

75 E. Martínez Ruiz y M. de P. Pi Corrales, Protección y seguridad en los Sitios Reales desde la Ilustración al liberalismo, Alicante, Universidad de Alicante, 2010, pp. 228 y 230.

76 Servicios, AGP, Personal, caja 686, exp. 3.

77 A. M. Moral Roncal, El enemigo en Palacio..., p. 83 y, del mismo autor, "Del rey abajo, ninguno': la depuración política de la real casa y patrimonio durante la crisis del Antiguo Régimen (1814-1835)", Historia Contemporánea, 29, (2005), pp. 905-906.

78 Memoria, AGP, Reinados. Fernando VII, caja 355, exp. 14.

79 Ibídem. Para otros reglamentos véase, D. del M. Sánchez González, "El tránsito de la casa de Fernando VII...", pp. 29-50. 
proponía "apoyar el desempeño del gran cargo y gobierno que V.M. se ha dignado confiar a mis débiles fuerzas" "80. En este reglamento aspiraba además a que el real patrimonio fuese menos gravoso y fomentase su utilidad y producción ${ }^{81}$, ya fuese variando el sistema interior de labores, por medio de jornaleros, a medidas para cesar o extinguir los oficiales y cargos actuales, así como mediante el desarrollo, según procediese, de plantíos de arbolado o cultivo de vegetales, granos o cría de ganados y aves para proveer los reales oficios y reales caballerizas ${ }^{82}$. Era importante poner en valor económicamente el real patrimonio, puesto que, salvo Aranjuez, San Fernando y la Acequia del Jarama, que daban beneficios, desde mayo de 1814 hasta finales de enero de 1821 los reales sitios habían producido un gravamen de más de 18 millones de reales a la hacienda en concepto de sueldos, pensiones y gastos de todas clases, a pesar de ser espacios muy productivos ${ }^{83}$.

En este contexto, el primero de marzo de 1822, se autorizó una visita de las posesiones reales que estaban reservadas al monarca y su familia, con el objeto de obtener por parte de la mayordomía mayor datos oportunos sobre la entidad, extensión y calidad de todos los bienes, los títulos de propiedad y posesión, su procedencia y todo lo que fuese indispensable para arreglar económicamente la administración de los mismos bienes y poder formar así un índice de ellos para proceder a identificar su extensión ${ }^{84}$. El resultado del trabajo del duque de Montemar, desde noviembre de 1820, fue la aprobación de un nuevo reglamento de 6 de junio de $1822^{85}$. En él, la contaduría y la tesorería tendrían un mayor control sobre los reales sitios al tener que supervisar los aprovechamientos y contratos de arrendamiento que en cada uno de ellos había, apuntar las quejas que se recibían e informar semanal y mensualmente al mayordomo mayor del estado de los caudales y de lo disponible en la caja ${ }^{86}$. El encargado de implementar el reglamento fue don José de Silva Waldstein, marqués de Santa Cruz, que sustituyó el 11 de julio de 1822 al duque de Montemar, apartado de la corte por su elevada edad ${ }^{87}$. Tampoco permaneció mucho tiempo al frente de la mayordomía el marqués de Santa Cruz, que fue impuesto por los constitucionalistas, ya que, el 20 de julio de 1823, el consejo de Regencia volvió a nombrar al conde de Miranda, persona de la entera confianza del soberano, para gestionar los cambios ${ }^{88}$.

\section{CONCLUSIONES}

Los años del Trienio supusieron un importante cambio en relación con la posesión y gestión del real patrimonio. Fernando VII anticipándose seguramente a las peticiones de los liberales capitaneó la cesión de parte de su real patrimonio a la Nación, lo que sin duda le beneficiaría, a pesar de que los bienes y posesiones enajenados fueron importantes. La jugada real supuso enfrentamientos entre los diputados de Cortes, muchos de los cuales

80 Memoria, AGP, Reinados. Fernando VII, caja 355, exp. 14.

81 La necesidad de recursos, dada la escasez de caudales, manifestaba el valor de un patrimonio tan importante. Situación de la tesorería, ibíd, caja 331, exp. 18.

82 Memoria, ibídem, caja 355, exp. 14.

83 Situación económica, ibídem, exp. 8.

84 Autorización, ibídem.

85 Reglamento, ibíd, caja 219, exp. 10 y A.M. Moral Roncal, "Reformismo y tradición en la corte española bajo el reinado de Fernando VII", Aportes, 41, (1999), pp. 42-44.

86 A. M. Moral Roncal, "La real casa y patrimonio en el reinado...", p. 159.

87 Expediente, AGP, Personal, caja 16.585, exp. 6.

88 Si bien, hasta octubre ejerció como interino el conde de la Puebla. Expediente, AGP. Personal, caja 686, exp. 3 y Memoria, Reinados, Fernando VII, caja 334, exp. 14. Así como, A.M. Moral Roncal, "Del rey abajo, ninguno'...", p. 908. 
consideraban que el monarca no seguía el espíritu de lo acordado en Cádiz, cuando se estableció que serían las Cortes y, por tanto, la Nación, la que decidiría sobre los bienes del real patrimonio ${ }^{89}$. Ahora bien, el fin del Trienio y el regreso al frente de la mayordomía del conde de Miranda supusieron un cambio de rumbo en relación con el real patrimonio. El proceso desamortizador de algunos de estos bienes, cedidos de manera "graciosa" por el soberano a la Junta Nacional del Crédito Público y puestos en el mercado a través de públicas subastas como bienes nacionales, se frenó ${ }^{90}$.

La Regencia, por real orden de 14 de junio de 1823, ordenaba la devolución de todos los bienes que habían sido separados del real patrimonio y consideraba nulas las ventas realizadas, reintegrándose al monarca de acuerdo con diferentes sentencias, derogándose así el deslinde del patrimonio real e iniciando una vía judicial que en muchos casos terminaría muchas décadas después ${ }^{91}$. La nulidad de las ventas se volvió a recoger en el decreto de 19 de noviembre de 1825, salvo de algunas pequeñas ventas, como las dehesas de Piul o de Párraces ${ }^{92}$. Asimismo, en este proceso, por reales órdenes de 1 de junio y de 12 de agosto de 1823 se anulaban las ventas de los bienes del clero regular y la devolución de los bienes enajenados y, por decreto de 2 de septiembre, se decían nulos la incorporación de las fundaciones piadosas y eclesiásticas al Estado ${ }^{93}$.

Todas estas disposiciones se reforzaron por real decreto de 8 de octubre de 1823, en el que se declaraban nulos y sin valor todos los actos del gobierno llevados a cabo entre el 7 de marzo de 1820 y el primero de octubre de 1823, ya que "en toda esta época he carecido de libertad, obligado a sancionar leyes, y a expedir las ordenes, decretos y reglamentos que contra mi voluntad se meditaban y expedían por el mismo gobierno"94. Fernando VII justificaba esta decisión por el gobierno tiránico que, en nombre de la Constitución, el gobierno liberal había realizado, el cual no era capaz de "reclamar el orden ni la justicia, ni podían tampoco conformarse con leyes establecidas por la cobardía y la traición, sostenidas por la violencia, y productoras del desorden más espantoso, de la anarquía más desoladora y de la indigencia universal"95.

En este proceso de vuelta al sistema anterior al pronunciamiento de Riego, en lo relativo al patrimonio real, se restableció por decreto de 16 de julio de 1823 la Junta Suprema Patrimonial de Apelaciones y el fuero de los oficiales de la Corona, por decreto de 25 de julio, poniendo fin a la abolición de los derechos privativos que se realizó en $1820^{96}$. De este modo, se aumentaba el control por parte de la Corona de la casa y del patrimonio, con la consiguiente desaparición de la tutela y vigilancia por parte de las Cortes, es decir, de la Nación. El mayordomo mayor era quien tenía, de forma privativa, la jurisdicción civil y

89 Un ejemplo de estos debates en E. García Monerris y C. García Monerris, Las cosas del rey..., pp. 74-79, 80-83.

90 Relación, AGP, AG, leg. 403.

91 F. Cos-Gayón, Historia jurídica del Patrimonio Real..., pp. 160-161 y AGP, AG, leg. 359. Informe, ibídem, leg. 1283, exp. 15. Algunos ejemplos, Juan Ranero y Benito Picabea por la compra de unos terrenos en San Fernando. Ibídem, leg. 865.

92 M. Merlos Romero, "El patrimonio inmueble de Aranjuez. Su evolución en el siglo XIX", Espacio, Tiempo y Forma. Historia del Arte, 8, (1995), p. 281.

93 M. Friera Álvarez, La desamortización de la propiedad de la tierra en el tránsito del Antiguo Régimen al Liberalismo (La desamortización de Carlos IV), Gijón, Fundación Foro Jovellanos del Principado de Asturias, 2007, pp. 249-250.

94 Decreto, AGP, Reinados, Fernando VII, caja 334, exp. 12.

95 Ibídem.

96 Memoria, ibídem, caja 335, exp. 29. 
criminal, en primera instancia, de los temas de la real casa y patrimonio, coexistiendo con los juzgados ${ }^{97}$.

El restablecimiento de la Junta Suprema se realizaba de acuerdo con lo dispuesto por el monarca en sus reales decretos de 22 de mayo de 1814 y 9 de agosto de 1815 para la separación del gobierno e intereses de su real casa de los demás del estado ${ }^{98}$ y lo que prescribía la ordenanza expedida al efecto el 8 de marzo de 1817. Esta Junta de Apelaciones tendría también competencias en el real patrimonio de la Corona de Aragón ${ }^{99}$ en donde volvería a ocupar sus puestos los bailes generales de Valencia, Barcelona y Palma de Mallorca, tras la depuración de sus oficiales llevadas a cabo por las Juntas Provinciales, teniendo que devolver los intendentes respectivos los papeles y efectos que les fueron entregados. Además, se indicaba que la Albufera y Valencia volvían a poder de los infantes Carlos María Isidro y Francisco de Paula Antonio en los términos de la reforma comunicada a la mayordomía mayor por la secretaría de Estado, el 25 de mayo de 1819. Asimismo, pasaría, de nuevo, a conocimiento de la mayordomía mayor el real valle de Alcudia, entrando sus productos en la tesorería de palacio, por cuenta de la real consignación, conforme a lo determinado por orden real de 28 de julio de $1815^{100}$.

La Junta Suprema Patrimonial estaría compuesta ahora por solo tres ministros togados: don Bernardo Riega, del Consejo y Cámara de Castilla, el conde de Torre Múzquiz, del Consejo de Indias y don José Caballero, que lo era de Hacienda, actuando como asesor general don Francisco Xavier ${ }^{101}$. El puesto de asesor general fue ocupado por Francisco Xavier, excepto para los sitios del Buen Retiro, Casa de Campo, la Florida y El Pardo, que competían a don Bernardo Riega, según lo dispuesto en los artículos 9 y 10 de las instrucciones publicadas por la Junta de Gobierno y de la Suprema de Apelaciones de la real casa y patrimonio de 1817. La vuelta al sistema anterior a marzo de 1820 también acarreó cambios en el personal. El fin del Trienio trajo consigo un proceso de depuración que comenzaría, en el caso de los oficiales de los reales sitios, el 24 de julio de 1823, cuando Fernando VII solicitó la relación de los criados que habían participado en las milicias voluntarias locales, decretando su separación definitiva del servicio el 14 de octubre de dicho año ${ }^{102}$.

\section{BIBLIOGRAFÍA}

Artola, M., Antiguo Régimen y revolución liberal, Barcelona, Ariel, 1983.

- La Hacienda del siglo XIX, progresistas y moderados, Madrid, Alianza Universidad, 1986.

Artola, M. y Flaquer Montequi, R., La Constitución de 1812, Madrid, lustel, 2008.

Brines Blasco, J. "Deuda y desamortización durante el Trienio Liberal" Moneda y Crédito, 124 (1973), pp. 51-67.

97 Competencias, AGP. AG, leg. 696. Asimismo, E. De Benito, "La Junta Suprema de Apelaciones de la Real Casa y Patrimonio", en Homenaje al profesor Alfonso García Gallo, Madrid, Universidad Complutense de Madrid, 1996, vol. 2, pp. 19-46.

98 Decretos, AGP. Reinados, Fernando VII, caja 379, exps. 20 y 21.

99 J. L. Sancho, La arquitectura de los Sitios Reales. Catálogo histórico de los palacios, jardines y patronatos reales del Patrimonio Nacional, Madrid, Patrimonio Nacional, 1995, p. 46.

100 Decretos, AGP. Reinados, Fernando VII, caja 379, exps. 20 y 21.

101 Competencias, ibídem, AG, leg. 696.

102 El 6 de agosto de 1823 llegaban las noticias de Aranjuez, el 12 de agosto de los oficiales de Madrid y de la Florida, entre otros. Listados, AGP, Reinados, Fernando VII, caja 334, exps. 11 y 14. Asimismo, A.M. Moral Roncal, El enemigo en Palacio..., pp. 107-108. 
Buldain Jaca, B. E., "El poder en 1820: la Junta Provisional y el Gobierno", Espacio, Tiempo y Forma. Serie V. Historia Contemporánea, 1, (1988), pp. 19-40.

Canga Argüelles, Memoria sobre el crédito público que presenta á los Córtes ordinarias de 1820 Don José Canga-Argüelles, Secretario de Estado, y del Depache universal de Hacienda de España y Ultramar, Madrid, García, 1820. Disponible en: http://mdz-nbnresolving.de/urn:nbn:de:bvb:12-bsb10362485-2

Colección de los decretos y órdenes que han expedido las Cortes Generales y Extraordinarias desde su instalación en 24 de septiembre de 1810 hasta igual fecha de 1811, Cádiz, Imprenta real, 1811. Disponible en: http://www.cervantesvirtual.com/obra-visor/ coleccion-de-los-decretos-y-ordenes-que-han-expedido-las-cortes-generales-yextraordinarias-desde-su-instalacion-en-24-de-septiembre-de-1810-hasta-igualfecha-de-1811--0/html/0027b5e4-82b2-11df-acc7-002185ce6064_128.html

Comín, F., Las cuentas de la hacienda preliberal en España (1800-1855), Madrid, Servicio de Estudios del Banco de España, 1990.

Cortina, T., Memoria que con motivo del dictamen de la comisión del Congreso de Sres. Diputados sobre Abolición del Real Patrimonio en la Antigua Corona de Aragón presenta al Excmo. Sr. Tutor de S.M. la Reina Doña Isabel II el consultor general de la Real Casa, Madrid, Aguado. Impresor de Cámara de S.M., 1842.

Cos-Gayón, F., Historia jurídica del Patrimonio Real, Madrid, Imprenta de Enrique de la Riva, 1881.

De Benito, E., "La Junta Suprema de Apelaciones de la Real Casa y Patrimonio", en Homenaje al profesor Alfonso García Gallo, Madrid, Universidad Complutense de Madrid, 1996, vol. 2, pp. 19-46.

Diario de las actas y discusiones de las Cortes. Legislatura de los años 1820 y 1821, Madrid, Imprenta especial de las Cortes, 1820, tomo II.

Diario de las Sesiones de las Cortes, ACD, 13 de julio de 1820, apéndice al número 9, vol. 3. Disponible en https://app.congreso.es/est_sesiones/

Díez Moreno, F., "La evolución constitucional del patrimonio nacional", Reales Sitios, núm. extra 1, (1989), pp. 15-30.

Fontana, J., Hacienda y Estado en la crisis del antiguo régimen español: 1820-1833, Madrid, Instituto de Estudios Fiscales, 1973.

- La quiebra de la Monarquía absoluta (1814-1820), Barcelona, Ariel, 1974.

Friera Álvarez, M., La desamortización de la propiedad de la tierra en el tránsito del Antiguo Régimen al Liberalismo (La desamortización de Carlos IV), Gijón, Fundación Foro Jovellanos del Principado de Asturias, 2007.

García Monerris, C. y García Monerris, E., "La nación y su dominio: el lugar de la corona", en Historia Constitucional. Revista electrónica, 5, (2004), pp. 161-190.

García Monerris, E. y García Monerris, C., "Monarquía y patrimonio en tiempos de revolución en España", Diacronie [En línea], 16.4, (2013), documento 4, Puesto en línea el 01 diciembre 2013, consultado el 30 abril 2019. URL: http://journals.openedition.org/ diacronie/855

- Las cosas del rey. Historia política de una desavenencia (1808-1874), Madrid, Akal, 2015.

Gaceta de Madrid, de 9 de mayo de 1820. Disponible en: https://www.boe.es/buscar/gazeta. php

Herr, R., "El significado de la desamortización en España", Moneda y Crédito, 131, (1974), pp. 57-94.

Labrador Arroyo, F., "Naturaleza y esencia de los artículos productivos". La situación del patrimonio real entre 1814-1820", Tiempos Modernos. Revista Electrónica de Historia Moderna, 39.2, (2019), pp. 488-512. 
La Parra López, E., Fernando VII: un rey deseado y detestado, Barcelona, Tusquets Editores, 2018.

López Rodó, L., El Patrimonio Nacional, Madrid, CSIC, 1954.

Madruga Real, A., "El Escorial a debate. Informes, discusiones y propuestas en las Cortes del siglo XIX", Anales de Historia del Arte, 11, (2001), pp. 291-312.

Martínez Ruiz, E. y Pi Corrales, M. de P., Protección y seguridad en los Sitios Reales desde la Ilustración al liberalismo, Alicante, Universidad de Alicante, 2010.

Merlos Romero, M., "El patrimonio inmueble de Aranjuez. Su evolución en el siglo XIX", Espacio, Tiempo y Forma. Historia del Arte, 8, (1995), pp. 273-304.

Moral Roncal, A. M., "Reformismo y tradición en la corte española bajo el reinado de Fernando VII", Aportes, 41, (1999), pp. 29-46.

- El enemigo en Palacio: afrancesados, liberales y carlistas en la Real Casa y Patrimonio (1814-1843), Alcalá de Henares, Universidad de Alcalá, 2005.

- "Del rey abajo, ninguno': Ia depuración política de la real casa y patrimonio durante la crisis del Antiguo Régimen (1814-1835)", Historia Contemporánea, 29, (2005), pp. 895-925.

- $\quad$ "La real casa y patrimonio en el reinado de Fernando VII (1814-1833)", en R. Sánchez y D. San Narciso (coords.), La cuestión de palacio. Corte y cortesanos en la España contemporánea, Granada, Comares, 2018, pp. 155-183.

Ortiz Córdoba, Á., Aranjuez, sitio, pueblo. Aranjuez, 1750-1841, Aranjuez, Doce Calles, 1992.

Pintos Vieites, M. del C., La política de Fernando VII entre 1814 y 1820, Pamplona, Studium Generale, 1958.

Sánchez González, D. del M., "El tránsito de la casa de Fernando VII a la de Isabel II: la Junta de Gobierno de la Casa Real y Patrimonio (1815-1840)", en Corte y Monarquía en España, Madrid, UNED, 2003, pp. 29-66.

Sancho, J. L., La arquitectura de los Sitios Reales. Catálogo histórico de los palacios, jardines y patronatos reales del Patrimonio Nacional, Madrid, Patrimonio Nacional, 1995.

Toboso Sánchez, P., "La Junta del Crédito Público en el Trienio Liberal", Revista de Estudios Políticos, 93, (1996), pp. 401-413.

Tomás y Valiente, F., El marco político de la desamortización en España, Barcelona, Ariel, 1972. 